
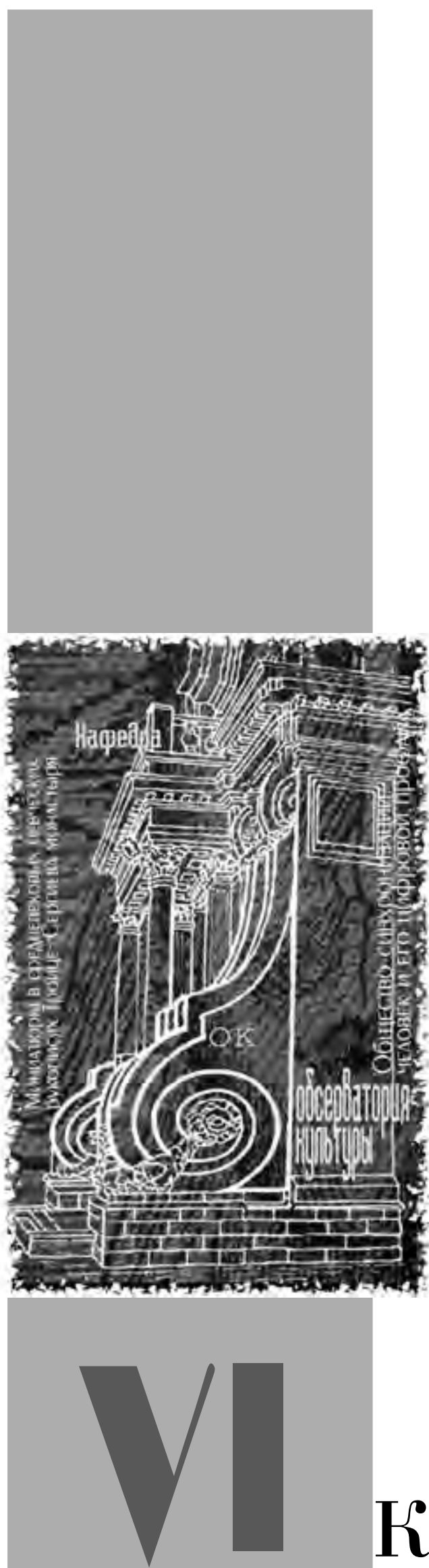

[...предзацита] ...

УДК 82.0

ББК 83.0

\section{А.В. АЛЕКСАНДРИНА}

\section{МИНИАТЮРЫ В СРЕДНЕВЕКОВЫХ ПЕВЧЕСКИХ РУКОПИСЯХ ТРОИЦЕ-СЕРГИЕВА МОНАСТЫРЯ}

Рассматривается нетрадиционное художественное оформление певческих крюковых рукописей Троице-Сергиева монастыря XV-XVI веков. На основе сходства миниатюры и анализа содержания сборника XVI века выявляется его монастырское происхождение. Исследуется уникальная миниатюра Октоиха $\mathrm{XV}$ века. Использованы рукописные источники фонда 304.I 0тдела рукописей Российской государственной библиотеки.

Ключевые слова: Троице-Сергиев монастырь, преподобный Сергий Радонежский, монастырская книгохранительница, певческие средневековые крюковые рукописи, миниатюра, Стихирарь, октоих.

$\mathrm{T}$ роице-Сергиев монастырь - крупнейший русский монастырь с более чем шестисотлетней историей. Основанная Сергием Радонежским в 40-е годы XIV века обитель обладала богатейшей книгохранительницей, основу которой заложил сам преподобный Сергий, переписывая книги, по свидетельству Иосифа Волоколамского, за неимением пергамента и бумаги, даже «на берестех» [1, с. 117]. В дальнейшем монастырская книгохранительница пополнялась рукописными, а затем и печатными книгами через переписывание, различные вклады, покупку, пожертвования до самого закрытия монастыря в 1919 году. Большая часть выдающегося по историко-художественному значению рукописного собрания Троице-Сергиева монастыря в настоящее время хранится в Отделе рукописей Российской государственной библиотеки, неизменно привлекая внимание иссле-

\title{
КАФЕДРА
}


дователей, в том числе изучающих богатую и уникальную орнаментику Троицких рукописей.

В библиотеке Троице-Сергиева монастыря находились выдающиеся образцы лицевых и орнаментированных русских рукописных книг разных веков. Наивысшего расцвета художественное оформление рукописей достигает в XVI веке, когда Троицкий монастырь становится центром русского книжного искусства. В это время в монастыре работают прекрасные писцы, такие как «чернец Вениаминишко», переписавший в 1522-1524 годах книгу Творений Дионисия Ареопагита (РГБ ф. 304.I № 123), инок Троице-Сергиева монастыря Исаак Собака - известный каллиграф, участвовавший в качестве писца в работах Максима Грека, и др. В это же время в монастыре работают великолепные орнаменталисты и миниатюристы, иллюминирующие книги новым типом орнамента, получившим в науке название «старопечатного». Прекрасные образцы этого орнамента можно обнаружить в Евангелии Исаака Бирёва 1531 года (РГБ ф. 304.III № 15), книге 0 постничестве Василия Великого 1556 года, переписанной иноком Исаией Каргопольцем (РГБ ф. 304.I № 133), в Апостоле тетр XVI века, переданном в 1747 году в Троицкую Духовную Семинарию, а затем в Московскую Духовную Академию [2, с. 13-14] (РГБ ф.173.1 № 5) и во многих других рукописях.

Певческие средневековые крюковые рукописи относятся к не самым богато украшенным типам рукописных книг. Ни окладные переплеты, ни миниатюры для них нехарактерны. Как правило, они украшены заставкой в начале рукописи, или в начале каждой книги сборника, или в начале разделов книги (например, перед каждым гласом Октоиха) и инициалами. Нередко встречаются певческие рукописи без заставок, единственным украшением которых является киноварный заголовок, открывающий рукопись, выписанный вязью или псевдовязью.

В собрании Троице-Сергиевой лавры, переданном в Российскую государственную библиотеку, сохранилось 43 крюковые рукописи XV-XVII веков, принадлежавшие ранее монастырской книгохранительнице ${ }^{1}$. Практически все они содержат те или иные украшения, характерные для рукописных книг этого периода. Стилистически их оформление весьма разнообразно и охватывает различные территориальные и временные типы, оставаясь в целом в рамках эволюции русского книжного орнамента. Однако две певческие Троицкие рукописи выделяются наличием в них миниатюр, сюжеты которых являются редчайшими, даже уникальными для певческих рукописей. Это Октоих 1480-х годов (РГБ ф. 304.I № 444) и Сборник певческий 1510-х годов (РГБ ф. 304.I № 411).

\footnotetext{
${ }^{1}$ Одна рукопись, ранее принадлежавшая книгохранительнице монастыря, в середине XVIII в. была передана в Духовную семинарию, а затем в Московскую Духовную Академию. Она хранится в составе фонда Духовной Академии в РГБ (ф. 173.I № 231). Еще одна рукопись из Троицкой библиотеки хранится в собрании Сергиево-Посадского государственного историко-художественного Музея-Заповедника (№ 274). Обе рукописи не содержат миниатюр.
}

Певческий сборник № 411 открывается страничной миниатюрой на л. II об.: Иисус Христос читает в синагоге в Назарете пророчество Исаии (Ис. 61, 1-2) о наступлении лета благоприятного (Лк. 4, 16-22). Миниатюра выполнена в красках с золотом, в живописном стиле, с тонкой прорисовкой лиц и одежд. В верхней части миниатюры изображен город Назарет, перед которым холмы, густо поросшие деревьями. К сожалению, левая верхняя часть миниатюры утрачена. Над миниатюрой цитата Евангелия от Луки (Лк. 4, 16): «[И пріиде в Назаретъ, и]дъже бъ воспитанъ». Эта миниатюра предваряет книгу Стихирарь и относится к службе Церковного Новолетия или Начала индикта, которое празднуется 1 сентября. В этот день в православной церкви на литургии читается Евангельское зачало о проповеди Христа. В этот же день - 1 сентября - празднуется память Симеона Столпника. Оба праздника отражены в заголовке на л. I, открывающем рукопись: «Стихарал месячныи с Богом починаем. Благослови отче. Индиктиону сиречь Новому лету и святого Симеона Столпника». Над заголовком расположена заставка неовизантийского стиля в красках на золотом фоне. На внешнем поле этого же листа помещена небольшая миниатюра, изображающая Симеона Столпника, стоящего на высоком столпе, к которому привязана корзина на длинной веревке (в красках). Заставка и миниатюра на полях объединены написанным у нижнего угла заставки изображением Бога, благословляющего Симеона. Изображение Бога и куколя Симеона Столпника выполнены одной - серо-синей краской. Таким образом, оба праздника, отмечаемые в первый день Церковного года (1 сентября), получили отображение в миниатюрах, что является уникальным для певческих рукописей.

Рассматривая миниатюры Московского круга первой половины XVI века, Н.В. Розанова указывает на несомненное сходство миниатюр «Проповедь Христа в синагоге» Сборника № 411 и Евангелия 1531 года Исаака Бирёва из Троице-Сергиевой лавры. «Архитектура, горки и лес на обоих миниатюрах повторены почти буквально. Они настолько близки, что трудно отказаться от предположения, что одна из них послужила образцом для другой. В таком случае образцом могла быть только миниатюра Евангелия Исаака Бирёва, так как в миниатюре Сборника нет нижней сцены и в архитектуре изображены не все постройки» [3, с. 273-274]. Несмотря на сходство миниатюр, исследовательница полагает, что они были выполнены разными мастерами: миниатюру из Сборника № 411 «писал русский художник, связанный с московской школой живописи, в которой еще живы были традиции Андрея Рублева», а происхождение миниатюры из Евангелия Бирёва «остается достаточно загадочным». По мнению исследовательницы, миниатюра, возможно, была выполнена заезжим мастером, работавшим при дворе Василия III, но, скорее всего, была привезена на Русь уже в готовом виде (в какой-либо другой книге или просто как миниатюра), вероятно, с Афона [3, с. 274]. Отметим, что рукопись № 411 выполнена на бумаге нескольких видов, датировка которых не выходит 


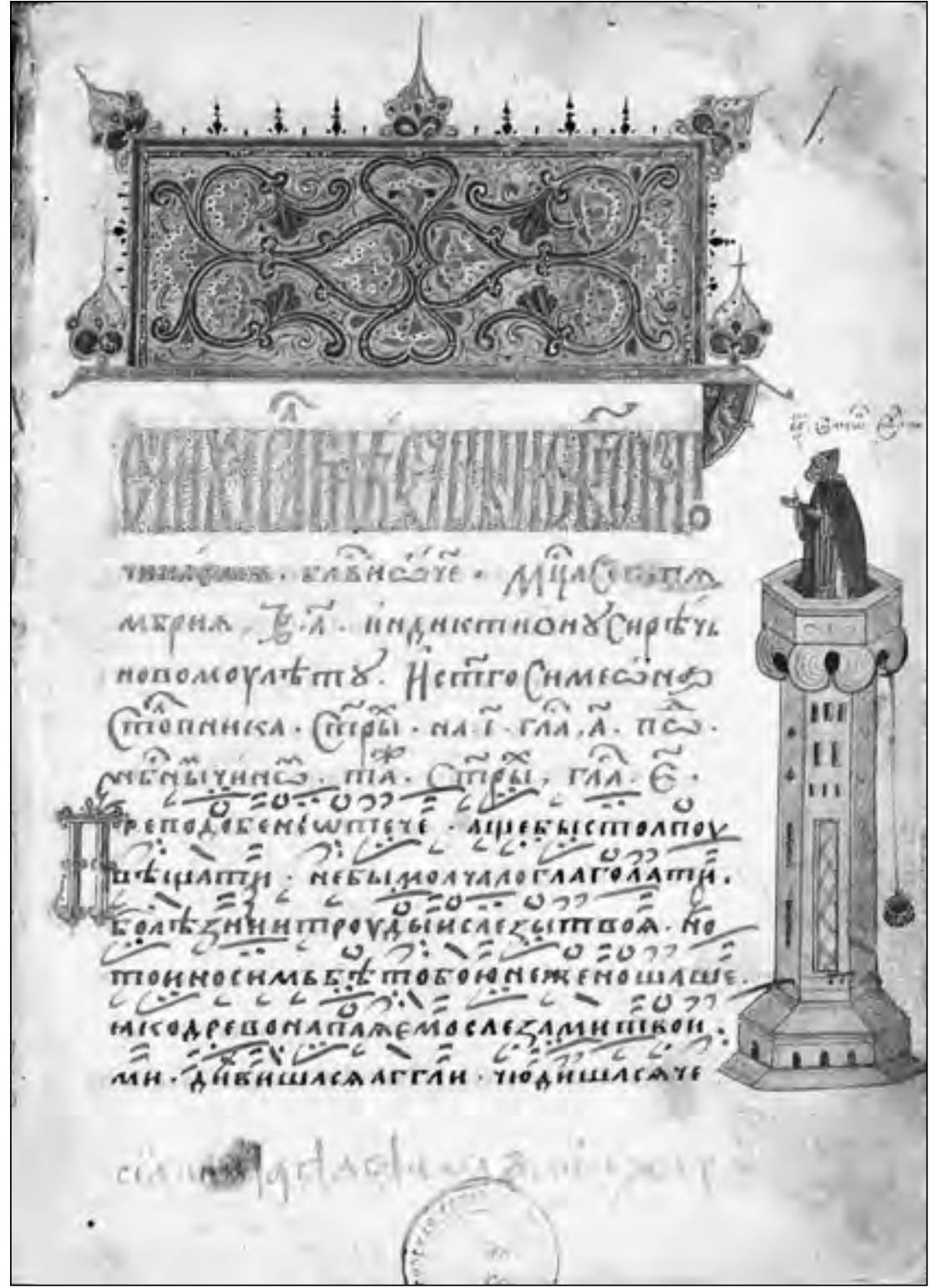

Начало книги Стихирарь из певческого сборника. РГБ ф. 304.I № 411

за границы 1510-х годов, однако водяные знаки защитных листов рукописи и листов, подклеенных при реставрации к листу I и листу II (с миниатюрой), относятся к 15301540-м годам (водяной знак: Гербовый щит под короной / «ІР» - тип: [4, № 1050 - 1530-1545 гг.], у Briquet над короной цветок, в рукописи его нет; и тип: [4, № 1591 1534 г.], у Лихачева нет короны). Более позднее происхождение защитных листов позволяет предположить, что после написания рукопись некоторое время находилась без переплета (на это указывают утраты на л. I, который исполнял роль обложки), а в 1530-1540-х годах была переплетена с восстановлением утраченных фрагментов. Причем, по-видимому, переплетена рукопись была уже не в монастыре, так как аналогов переплету сборника № 411, а точнее его накладным металлическим элементам, в собрании Троице-Сергиевой лавры нет. Переплет № 411 представляет собой доски в коричневой коже с тиснением, традиционно дополненные на нижней крышке четырьмя полусферическими жуковинами и таким же средником. Накладные украшения верхней крышки уникальны: средник представляет собой небольшой металлический круг, на котором отчеканен лев, напавший на коня (или оленя) и терзающий его спину. На фигурных наугольниках верхней крышки изображены два животных, вероятно коня, обращенных друг к другу. Этот сборник вложил в ТроицеСергиев монастырь епископ Досифей Забела, который в 1506-1507 годах был настоятелем Троицкого монастыря, а 23 января 1508 года был возведен в сан епископа Сарского и Подонского (Крутицкого). 06 этом повествует запись, оставленная на листах рукописи: «Сия книга глаголимая стихарал владыки Дософея Сарского и Подоньскаго. А дал его в храм Живоначалной Троице Сергиева манастыря». Умер Досифей 2 февраля 1544 года [6, стб. 1034]. Таким образом, время поступления рукописи в монастырь ограничивается 1544 годом. Необычность и уникальность украшений переплета, более не встречающихся в Троицких рукописях, указывает, вероятно, на то, что переплеталась рукопись в другом месте. Возможно, епископ Досифей в 15301540-е годы (датировка защитных листов рукописи) велел отреставрировать и переплести певческий сборник, созданный в Троице-Сергиевом монастыре, чтобы вложить его в монастырь, настоятелем которого он был раньше.

Кроме сходства миниатюр на Троицкое происхождение рукописи указывает и сходство ее содержательной части с содержанием рукописи, принадлежавшей книгохранительнице монастыря. Содержание сборника № 411 позволяет говорить о вероятности его написания именно в Троицком монастыре.

Одним из первых певческих сборников, значащихся в книгохранительнице монастыря по самой старшей сохранившейся монастырской описи 1641 года, является сборник 1480-1490-х годов (РГБ ф. 304.I № 421), на листах которого подписано «Княж Варламовской 0боленсково». Владелец этой рукописи был певчим левого клироса Троицкого монастыря в 1510-х годах. Содержание книги Стихирарь из сборника № 421 совпадает с содержанием Стихираря из Сборника № 411: дни памяти святых, отличные от современных дат, совпадают; одни и те же 
стихиры в службах нотированы, одни и те же не нотированы; после Стихираря помещены одинаковые прибавления; гласовые обозначения в многогласниках, включая пропуски, совпадают. Отличия Стихирарей связаны с различным временем их написания. Так, в сборнике № 411 есть несколько указаний святым, которых нет в № 421, так как время их прославления более позднее, чем время написания рукописи № 421, и элементы старого истинноречия, встречающиеся в сборнике № 421, изменены в более поздней рукописи № 411 на раздельноречные. Помимо основного музыкального крюкового чернильного текста в сборнике № 421 часто киноварью приписаны варианты распевов. Музыкальный текст № 411 совпадает с основным музыкальным текстом № 421. Bсе перечисленные факты позволяют говорить о том, что, вероятно, протографом для лицевого Стихираря из № 411 являлся Стихирарь № 421, находящийся в тот момент в Троице-Сергиевом монастыре. Аналогичную ситуацию мы видим и в Триодной части сборников. Показателен славник шестой Недели поста (Цветоносия) «Да пророческая скончаютеся <...> ». В № 421 он нотирован только фрагментарно в первой строке, далее не нотирован, а в № 411 первая строка содержит идентичную фрагментарную нотацию, со второй строки славник нотирован целиком. Вероятно, писец при написании рукописи № 411 пользовался дополнительным источником, полностью нотированным. В обеих рукописях (№ 411 и 421) в Октайной части во втором гласе стихиры воскресны на «Господи воззвах» великой вечерни выписаны не на великой вечерне, как у других гласов, а на малой вечерне перед богородичном-славником. При этом в обеих рукописях присутствует идентичный заголовок: «Глас 2-й на малой вечерни стихиры по обычаю, на великой вечерни стихиры воскресны». Все эти наблюдения, вместе с наблюдениями над художественным оформлением сборника, высказанные Н.В. Розановой, позволяют говорить о Троицком происхождении уникальной певческой рукописи № 411 и, следовательно, о наличии в монастыре в начале XVI века высокопрофессионального художника со своим видением певческой книги.

Еще одна певческая Троицкая рукопись, украшенная миниатюрой, относится к 1480-м годам. 0ктоих 1480-х годов упоминается уже в первой сохранившейся описи Троице-Сергиева монастыря 1641 года. Происхождение его неизвестно. На обороте верхней крышки находится запродажная запись (XVI ? в.): «А сю книгу продал Юрью Дмитрей Трубицин». Сведений о Дмитрии Трубицине найти не удалось, но в писцовой книге города Каширы и Каширского уезда 1578-1579 годов, упоминается Семен Дмитриевич Трубицын, возможно, сын Дмитрия. Род Трубицыных упоминается также в писцовых книгах Орловского уезда 1594-1595 годов [7, с. 917, 1050, 1363 и др.].

Октоих № 444 из собрания Троице-Сергиевой лавры традиционно разделен по количеству гласов на 8 частей, каждая из которых открывалась киноварным заголовком, написанным вязью, и заставкой или миниатюрой. К сожалению, 4 украшения - перед четными гласами были утрачены уже к середине XIX века, на что указывает иеромонах Арсений: «Пред каждым гласом были 


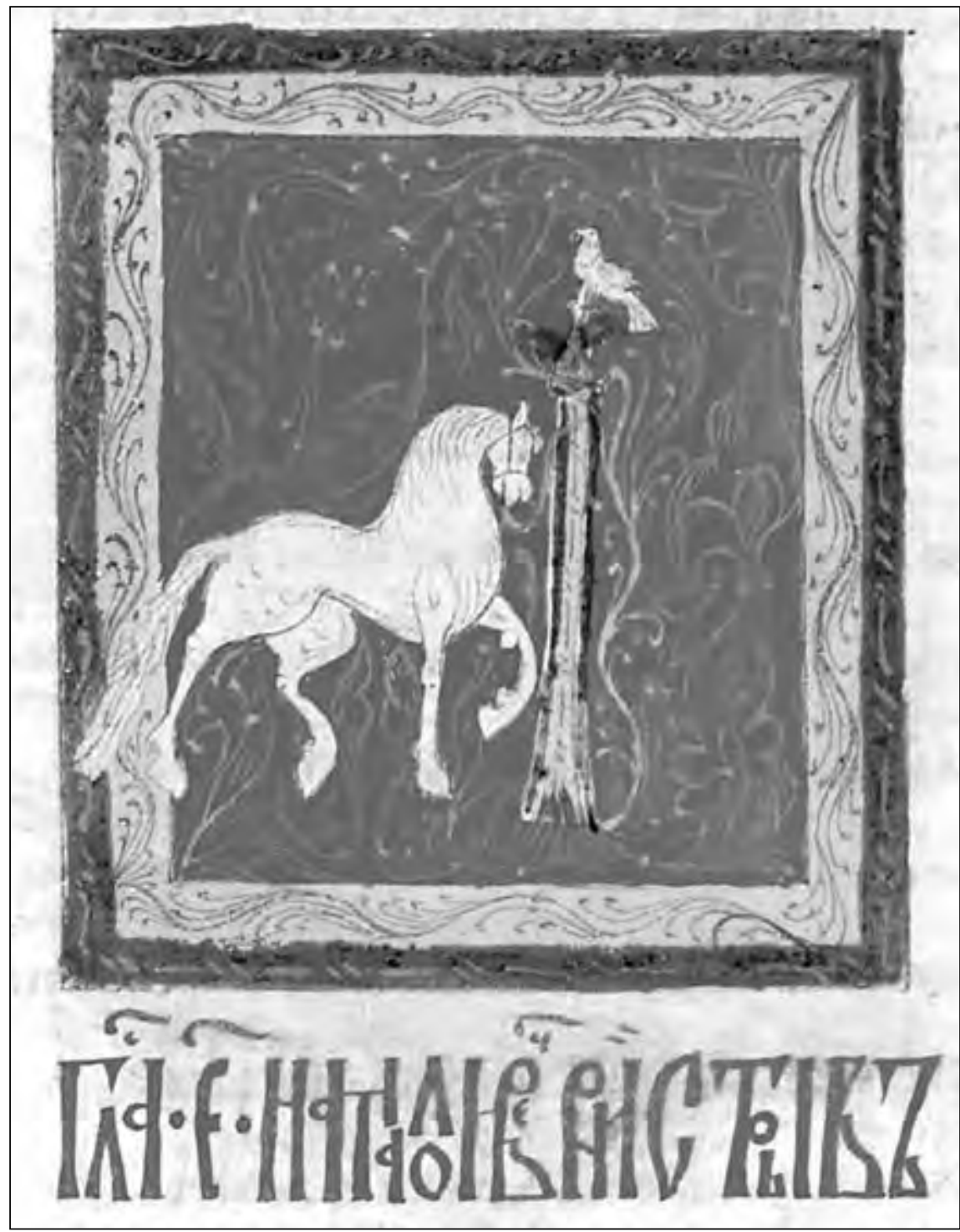

Миниатюра перед песнопениями 5-го гласа из Октоиха. РГБ ф. 304.I № 444 по золотому фону; 2) с растительным фантастическим орнаментом желтой краской по черному фону, с киноварными элементами на рамке; и 3) балканского стиля, в виде двух кругов переплетенных полукругами, выполненных киноварью по зеленому, синему и желтому фону с жемчужинами. Опираясь на родство орнамента Троицкой рукописи с орнаментом рукописей, написанных в Москве, Т.Б. Ухова предположила, что рукопись могла иметь московское происхождение [9, с. 18-19]. Три заставки перед 1, 3 и 7-м гласами выполнены в разных стилях и разными красками. Две из них - неовизантийского и балканского орнамента - являются традиционными для рукописей XV-XVI веков. Заставка перед 3-м гласом имеет оригинальный растительный орнамент, выполненный приглушенно-желтой краской по черному фону. У заставки широкая желтая рамка с выписанными по ней тонкими коричневыми травами, на нижней планке рамки две звериные головы с высунутыми киноварными языками. Стиль оформления рамки, использование одинаковых красок с теми, которыми написана миниатюра перед 5-м гласом, позволяют предположить, что оба этих украшения принадлежат одному мастеру. Кроме того, вязь в заголовках перед 3-м и 5-м

нарисованы разныя красивыя заставки, уцелели при 1, 3,5 и 7, прочия оторваны» [8, Ч. II, с. 150]. Наибольший интерес представляет изображение коня, помещенное перед 5-м гласом. Изображение животных, в частности коня, нехарактерно для певческих средневековых рукописей. Тем неожиданней его появление в 0ктоихе 1480-х годов № 444. Перед песнопениями 5-го гласа помещена полстраничная миниатюра, изображающая белого коня, привязанного к столбу, на котором сидит птица. Исполнение миниатюры очень изящно: по красному фону выписаны тончайшие полупрозрачные белые травы, миниатюра помещена в двойную широкую раму: внутренняя часть ее приглушенного желтого цвета с тонко выписанными коричневыми травами, внешняя - коричневая с тонким белым узором. Под миниатюрой киноварью выписан обычный заголовок: «Глас 5-й начало вечерни стихиры въскресны». Перед гласами 1, 3 и 7-м расположены заставки: 1) неовизантийского стиля с плотной раскраской гласом также выполнена одной рукой. Стиль и краски у заставок с «традиционным» орнаментом (перед 1-м и 7-м гласами), а также вязь соответствующих заголовков иные, как, вероятно, и авторы. Оригинальность художника, поместившего в певческую рукопись миниатюру с изображением коня, заключается еще в том, что для русских рукописей (и певческих и непевческих) характерны миниатюры, находящиеся в более или менее близкой связи с текстом либо изображающие авторов книги (Евангелистов, Иоанна Дамаскина и других), размещение же миниатюр аллегорического или символического типа уникально.

Исследование миниатюр певческих рукописей Троице-Сергиева монастыря проливает свет на их происмонастыре, а также открывает перспективы в изучении певческих монастырских рукописей с точки зрения их художественного оформления. хождение, иногда помогая выявить созданные в самом 


\section{Список литературы}

1. Летопись наместников, келарей, казначеев, ризничих, экономов и библиотекарей Свято-Троицкой Сергиевой лавры // Летопись занятий археографической комиссии. 1865-1866 гг. - СПб.: Изд. Археографической комиссии, 1868. - Вып. 4. - С. 62-130.

2. Леонид, архим. Сведение о славянских рукописях, поступивших из книгохранилища св. Троицкой Сергиевой лавры в библиотеку Троицкой духовной семинарии в 1747 году (ныне находящихся в библиотеке Московской Духовной Академии) // чОИДР. - М., 1883. - Кн. 4. - С. 1-112; М., 1884. - Кн. 3. - C. 113-264, Кн. 4. - C. 265-296; М., 1885. - Кн. 1. - С. 297-375.

3. Розанова Н.В. Памятники миниатюры Московского круга первой половины XVI века // Древнерусское искусство. Художественная культура Москвы и прилежащих к ней княжеств XIV—XVI вв. - М.: Наука, 1970. - С. 258274.

4. Briquet C.M. Les filigranes. Dictionnare historique des Marcues du papier des leur apparition vers 1282 jusque'n 1600. Avec
39 figures dans le texte et 16,112 fac-similes de filigranes. Leipzig: Verlag von Karl W. Hiersemann, 1923. - T. 1-4. $836 \mathrm{p}$.

5. Лихачевъ Н.П. Палеографическое значение бумажныхъ водяныхъ знаковъ. - Часть III: Альбомъ снимковъ. - СПб.: ОЛДП, 1899.

6. Строев П. Списки иерархов и настоятелей монастырей российския церкви. - СПб.: Изд. Археографической комиссии, 1877. - X + 1056 стб. + 68 стб.

7. Писцовыя книги Московскаго государства / под ред. действительнаго члена Н.В. Калачова. - СПб.: Изд. Императорскаго русскаго географическаго о-ва, 1877. - Ч. 1: Писцовыя книги XVI века. - Отд. 2: Местности губерний: Ярославской, Тверской, Витебской, Смоленской, Калужской, Орловской, Тульской. - $1598+[5]$ с.

8. [Илларий, иером., Арсений, иером.]. Описание славянских рукописей библиотеки Свято-Троицкой Сергиевой лавры. - М.: Изд. ОИДР, 1878. - Ч. 1-3.

9. Ухова Т.Б. Миниатюры, орнамент и гравюры в рукописях библиотеки Троице-Сергиева монастыря // Записки Отдела рукописей. - М.: Изд. ГБЛ, 1960. - Вып. 22. - С. 5-56.

\section{B.H. MOИCEEB}

\section{ОБЩЕСТВО СИНХРОНИЗАЦИИ: ЧЕЛОВЕК И ЕГО ЦИФРОВОЙ ПРОФАЙЛ}

Статья посвящена осмыслению новых медиа. Анализируя современную цифровую культуру, автор критикует представление о «виртуальной реальности» как о некой параллельной реальности; он предполагает, что парадигма онлайн — офлайн теряет свою актуальность, а повсеместное проникновение интернет-технологий приводит к синхронизации человека с его цифровым профайлом. Ключевые слова: новые медиа, виртуальная реальность, тело без органов, синхронизация, цифровой профайл, медиафилософия, визуальный поворот, образ.

оследние полтора десятилетия можно смело назвать временем большого взрыва новых медиа. Twitterреволюции и бесконечные фотографии еды в Instagram, сотни незнакомых нам «друзей» на Facebook и постоянные push-уведомления в смартфоне незаметно, но бесповоротно захватили жителя современного мегаполиса. Развитие высоких технологий навсегда изменило самые привычные социальные ритуалы вроде употребления пищи или проезда в общественном транспорте. Естественно, этой экспансии новых медиа уделяют пристальное внимание публицисты и социологи, об этом пишут колонки (очень часто гневные и пессимистичные) и целые книги.

Несмотря на популярность явления и пристальное внимание к нему, знание о новых медиа только формируется. Существенная сложность в описании новых медиа состоит в том, что это невероятно динамичная среда. Актуальные сервисы и технологии трансформируются и устаревают, новые ритуалы видоизменяются в режиме онлайн. Но динамичность - не главная сложность на пути системного осмысления новых медиа. Еще одной проблемой является не столько отсутствие, сколько невозможность сформировать какой-то общий подход или представление о том, чем являются новые медиа и зачем они нужны человеку, по крайней мере, на данный момент. Поэтому для начала следует уточнить, что мы понимаем под этим термином.

Вполне возможно, что количество попыток определить, что такое новые медиа, уже превысило огромный список дефиниций слова «культура». Популяризатор медиафилософии Валерий Савчук пишет об интуитивной ясности и очевидности новых медиа, и с этим сложно не согласиться [1]. Но при всей ясности в научных кругах до сих пор ведутся споры и царит терминологическая неразбериха. 